\title{
NDP leader charges feds with "bullying"
}

$\mathrm{T}$

he federal government has been "bullying" Canadians instead of governing with respect to recent decisions in health care, Thomas Mulcair, leader of the Official Opposition and the New Democratic Party (NDP) told delegates on the final day of the Canadian Medical Association (CMA) annual meeting in Ottawa.

In a speech that was surprisingly partisan for a CMA meeting, Mulcair said that there have been two examples of the federal government's "heavy-handed and demagogic approach" to health care in the past week. "They unsuccessfully tried to recruit Canadian doctors in their ideological crusade against marijuana. And they tried to force doctors to decide who should and shouldn't get home mail delivery. That's not governing. That's bullying."

Mulcair is the first leader of the Official Opposition to be invited to address the CMA General Council.

He accused the federal government of being "more interested in defunding public health care than protecting it" and "in dictating to provinces and providers rather than working with them." A recently announced plan to cut $\$ 36$ billion from federal transfers starting in 2016 "would be a return to the dark days of the 1990s," he said. "We'll never play a constructive role with our provincial and territorial partners, if we return to an era of crippling cuts."
An anticipated budget surplus in 2015 should be used to cancel proposed cuts to health care, maintained Mulcair.

Although money may not be the solution for problems facing health care, it is "definitely a necessary precondition," he said. "Mr. Harper, it's time to keep your word to protect Canadian health care."

In keeping with an underlying theme of the annual meeting, Mulcair pointed to seniors care as a primary health care challenge and later told reporters that he favours a Royal Commission on physician-assisted suicide. The NDP is the only federal party with a national strategy for seniors care, including a policy on aging and palliative care.
In his speech to CMA, Mulcair quickly moved on to other challenges, criticizing federal cuts to refugee health as "cruel and thoughtless."

He also decried the "awful" state of some First Nations' reserves and food security in Canada. "It's totally unacceptable ... that 800000 children go to school each day without having eaten." The NDP is the first federal party with a pan-Canadian food strategy.

On the topic of military health, Mulcair slammed the government for shutting down nine Veterans Affairs service centres this year and pledged to reopen them if elected.

"Our military is grappling with the impact of a decade of war in Afghanistan. We have a wave of new veterans. ... They need, they deserve, our full support."

Mulcair said he wrote to Prime Minister Stephen Harper earlier this year, asking him to make military suicides and mental health a personal priority. "He never bothered to respond." A call to reverse \$200 million in cuts in Veterans Affairs also fell on deaf ears.

"The main challenge we face ... is to honour these responsibilities," said Mulcair. "What our medical professionals need, what you deserve, is a federal government that will be a partner in making that change." - Barbara Sibbald, CMAJ

CMAJ 2014. DOI:10.1503/cmaj.109-4886 